\title{
Optimization of direct acid esterification process of soybean oil deodorizer distillate
}

\author{
By Nara Lúcia Facioli and Daniel Barrera-Arellano* \\ Laboratório de Óleos e Gorduras - Faculdade de Engenharia de Alimentos (FEA) - \\ Universidade Estadual de Campinas (UNICAMP), Caixa Postal 6091, CEP 13083-970, \\ Campinas, SP, Brazil. \\ E-mail: daniel @fea.unicamp.br
}

\section{RESUMEN}

Optimización del proceso de esterificación ácida directa del destilado de desodorización del aceite de soja.

En este estudio fueron optimizadas las condiciones de reacción de esterificación ácida directa de los ácidos grasos libres de destilado de desodorización del aceite de soja, usando alcohol etílico anhidro y ácido sulfúrico concentrado como catalizador. Fueron determinadas las mejores condiciones de proceso para obtener las tasas de conversión más altas de ácidos grasos libres en ésteres etílicos, manteniendo los tocoferoles. Los resultados fueron analizados mediante la metodología de superficie de respuesta usando un delineamiento experimental factorial completo de segundo orden. Las condiciones óptimas encontradas para la esterificación ácida directa del destilado de desodorización del aceite de soja obtenidas fueron: etanol:ácidos grasos libres entre 6.4 y $11.2: 1$, concentración de ácido sulfúrico entre 0.9 y $1.5 \%$ y tiempo de reacción entre 1.3 y $2.6 \mathrm{~h}$, obteniendo tasas de conversión mayores que $94 \%$. No fueron observadas pérdidas significativas de tocoferoles durante el proceso. Los resultados mostraron un buen ajuste entre el modelo matemático y las respuestas experimentales para las diferentes condiciones del proceso, lo que permite considerar el modelo como predictivo y estadísticamente significativo $(p<0.05)$.

KEY-WORDS: Destilado de desodorización - Esteres etílicos Esterificación -Tocoferoles.

\section{SUMMARY}

Optimization of direct acid esterification process of soybean oil deodorizer distillate.

In this research work, the reaction conditions for the direct acid esterification of free fatty acid from soybean oil deodorizer distillate was optimized, using anhydrous ethyl alcohol and concentrated sulfuric acid as catalyst to determine the best process conditions to get the best conversion rates of free fatty acids to ethylic esters, preserving the tocopherols. The conversion extent of free fatty acids to ethyl esters was optimized using a Response Surface Methodology obtained through a second order factorial experimental design. The optima conditions for the direct acid esterification of soybean oil deodorizer distillate were: ethanol:free fatty acids from 6.4 to $11.2: 1, \mathrm{H}_{2} \mathrm{SO}_{4}$ concentration from 0.9 to $1.5 \%$ and reaction time from 1.3 to $2.6 \mathrm{~h}$, with conversions extent above $94 \%$. No significant tocopherol losses were observed during the process. Results showed a good fit between mathematical model and data obtained at different processing conditions, making this model predictive and statistically significant $(p<0,05)$.

KEY-WORDS: Deodorizer distillate - Esterification - Ethyl esters - Tocopherols.

\section{INTRODUCTION}

Soybean oil is the most important vegetable oil commercialized all over the world and its deodorizer distillate is a valuable by-product obtained during the deodorization process, representing from 0.15 to $0.45 \%(\mathrm{w} / \mathrm{w})$ of the oil to be deodorized. Soybean oil deodorizer distillate (SODD) is a complex mixture of free fatty acids (FFA), sterols and their esters, tocopherols, mono-, di- and triacylglycerides, hydrocarbons, oxidation products, aldehydes, ketones and others, being the main raw material for the production of vitamin $\mathrm{E}$ and high-value products (Pryde, 1980). The price of this distillate is based on its content of tocopherol, which is normally between 8 to $12 \%$ of the distillate weight (Woerfel, 1981).

Several processes are used in the manufacturing of tocopherol and sterol concentrates. Commercially, the most important is molecular distillation, in which these compounds are processed at reduced pressure and temperature (Ramamurthi et al., 1991).

In the process of preparing tocopherol and sterol concentrates, the fatty acids present in the deodorizer distillate are esterified using chemical or enzymatic means in order to reduce their boiling points thereby facilitating their separation from the desired compounds (Kim and Rhee, 1982). The utilization of ethanol in fatty acid esterification is justified by the fact that it is on the GRAS list as opposite to toxic methanol. However, while some of these processes have been commercially acceptable, none have been completely satisfactory since these involve admixing large quantities of alkali and the like with the sludge in order to hydrolyze and saponify the esters that are present. These quantities are stoichiometrically in great excess in order to obtain maximum hydrolysis and saponification. So, this significantly reduces the tocopherols levels because they are extremely labile under basic $\mathrm{pH}$ (Brokaw and Smith, 1964). In a previous study, the same authors have esterified the SODD FFA 
refluxing for 1 hour, methanol:SODD = 1:3 and $\mathrm{HCl}: S O D D=1: 20$, by weight. However, it is difficult to find the best conditions for maximum ester yield, due to the individual and interaction effects that exist among the following factors: reaction time, $\mathrm{H}_{2} \mathrm{SO}_{4}$ concentration, reactants ratio, presence of impurities and moisture content in reaction medium to produce tocopherol/sterol concentrates (Ramamurthi et al., 1991). In such cases, response surface methodology (RSM) is highly recommended, because, because it offers a solution to multivariable optimization problems (Box, 1978; Khuri and Cornell, 1987; Barros Neto et al., 1996). In this study, the direct acid esterification process conditions of SODD saponifiable matter were optimized for ethyl ester production by means of RSM.

\section{EXPERIMENTAL}

\subsection{Material}

\section{Soybean Oil Deodorizer Distillate (SODD)}

SODD (deodorization conditions: temperature ca. $240^{\circ} \mathrm{C} ; 0.4 \mathrm{~mm} \mathrm{Hg}$ pressure; $4 \mathrm{~kg} \mathrm{~s}^{-1}$ steam) was supplied by COCAMAR-Cooperativa de Cafeicultores e Agropecuaristas de Maringá Ltda. (Maringá, PR-Brazil). It had a brown color and semi-solid texture at $25^{\circ} \mathrm{C}$ and contained $0.24 \%$ moisture (AOCS Tb 2-64, 1995). SODD was stored at $-18^{\circ} \mathrm{C}$ and liquefied for use, at $40^{\circ} \mathrm{C}$ in an oven.

\section{Chemicals}

Unless otherwise specified, all chemicals were reagent grade. Tocopherol $(\alpha-, \beta-, \gamma-$ and $-\delta)(99 \%)$ and sterol [stigmasterol $(90 \%), \beta$-sitosterol $(60 \%)$ and campesterol (40\%)] standards were purchased from Sigma Chemical Co. and from Merck. The absolute ethanol used in the esterification reaction was purchased from Labsynth Produtos para Laboratório Ltda.

\subsection{Analytical methods}

Tocopherols: The tocopherol content was determined according to AOCS method Ce 8-89 (1993). The quantification of each isomer $(\alpha-, \beta-, \gamma-$ and $\delta$ - tocopherols) was performed using a standard curve, prepared under the same conditions as the analysis. A Perkin Elmer LC 250 high-pressure liquid chromatograph, equipped with a Shimadzu fluorescence detector, with excitement at $290 \mathrm{~nm}$ and emission at $330 \mathrm{~nm}$, and a Merck LiChrosorb Si 60 column ( $25 \mathrm{~cm} \times 4 \mathrm{~mm}, 5 \mu \mathrm{m})$ was used. Mobile phase was hexane:iso-propyl alcohol $(99: 1, \mathrm{v} / \mathrm{v})$, at a flow rate of $1.1 \mathrm{~mL} / \mathrm{min}$.

Sterols: The sterol content was determined according to Holen (Holen, 1985), using a Perkin
Elmer LC 250 high-pressure liquid chromatograph, equipped with a Perkin Elmer LC 290 UV/Vis spectrophotometric detector with wavelength $(\lambda)$ of $206 \mathrm{~nm}$ and a Supelco Supelcosil C-8 column $(25 \mathrm{~cm}$ $x 4.6 \mathrm{~mm})$. Mobile phase was acetonitrile:water $(80: 20, \mathrm{v} / \mathrm{v})$, at a flow rate of $1.6 \mathrm{~mL} / \mathrm{min}$. The quantification individual sterols (campesterol, stigmasterol and $\beta$-sitosterol) was conduced using a standard curve, prepared under the same conditions as the analysis.

Lipids classes: Glycerides were determined and analyzed by high performance size exclusion chromatography, according to Dobarganes and Márquez-Ruiz (1993), with a Perkin Elmer Series 10 high-pressure liquid chromatograph, equipped with a refraction index Sicon Analytic LCD 201 detector and two HP PL gel columns $(30 \mathrm{~cm} \times 7.5 \mathrm{~mm}, 5 \mu \mathrm{m})$, of $100 \AA$ and $500 \AA$ connected in series. Mobile phase was tetrahydrofuran, at a flow rate of $1.0 \mathrm{~mL} / \mathrm{min}$. Free fatty acids, mono-, di- and triacylglycerols were determined by internal normalization of the areas.

\subsection{Statistical method}

Experimental design: Initially, an incomplete factorial design was used to study and verify the effects of the independent variables [reaction time $\left(X_{1}\right), \mathrm{H}_{2} \mathrm{SO}_{4}$ concentration $\left(\mathrm{X}_{2}\right)$ and ethanol:FFA molar ratio $\left(X_{3}\right)$ ] on the response (preliminary experiments not presented). To study the effect of the independent variables as a linear term, quadratic term and interactions (cross product) on the response $Y$ (extent of conversion of FFA to ethyl esters) and optimize the results, RSM was used, obtained through a complete factorial design (Table I). A Central Composite Rotational Design (CCRD) with three independent variables (Table II), 8 factorial points, 3 central points (replicates) and 6 axial points was used (Khuri and Cornell, 1987). The significant differences were tested at the $95 \%$ confidence interval based on the F-test (Barros Neto et al., 1996).

The statistical analysis and optimization of SODD FFA direct acid esterification process with ethanol was accomplished using "STATISTICA for Windows 5.0" software [StatSoft, Inc, Tulsa, OK (1995)].

Experimental validation: The validation of the statistical experimental model was accomplished under conditions selected among the best results indicated by SRM.

\subsection{Esterification reaction}

One hundred $\mathrm{g}$ of SODD and selected amounts of anhydrous ethanol and concentrated sulfuric acid were placed in a $500 \mathrm{~mL}$ round-bottom flask and stirred magnetically at $80^{\circ} \mathrm{C}$ of temperature. The reaction course was followed by determining the acid value (AV) (AOCS Te 1a-64, 1993) of the product as 
Table I

Combination of coded levels for a complete factorial design of three variables for the direct acid esterification process of soybean oil deodorizer distillate (SODD) and the conversion (\%) of free fatty acids (FFA) to ethyl esters

\begin{tabular}{|c|c|c|c|c|}
\hline \multirow{2}{*}{ Trial $^{a}$} & \multicolumn{3}{|c|}{ Coded level } & \multirow{2}{*}{$\begin{array}{c}\text { Conversion } \\
(\%)^{b}\end{array}$} \\
\hline & $X_{1}$ & $X_{2}$ & $X_{3}$ & \\
\hline 1 & -1 & -1 & -1 & $63.6 \pm 0,87$ \\
\hline 2 & +1 & -1 & -1 & $65.1 \pm 0,46$ \\
\hline 3 & -1 & +1 & -1 & $69.9 \pm 0,10$ \\
\hline 4 & +1 & +1 & -1 & $64.7 \pm 0,47$ \\
\hline 5 & -1 & -1 & +1 & $78.8 \pm 0,08$ \\
\hline 6 & +1 & -1 & +1 & $83.4 \pm 0,27$ \\
\hline 7 & -1 & +1 & +1 & $87.8 \pm 0,35$ \\
\hline 8 & +1 & +1 & +1 & $91.9 \pm 0,51$ \\
\hline 9 & -1.68 & 0 & 0 & $81.4 \pm 0,57$ \\
\hline 10 & +1.68 & 0 & 0 & $93.3 \pm 0,39$ \\
\hline 11 & 0 & -1.68 & 0 & $75.0 \pm 0,06$ \\
\hline 12 & 0 & +1.68 & 0 & $92.8 \pm 0,61$ \\
\hline 13 & 0 & 0 & -1.68 & $45.6 \pm 0,48$ \\
\hline 14 & 0 & 0 & +1.68 & $94.1 \pm 0,42$ \\
\hline $15(C)$ & 0 & 0 & 0 & $93.9 \pm 0,09$ \\
\hline $16(C)$ & 0 & 0 & 0 & $92.5 \pm 0,72$ \\
\hline $17(\mathrm{C})$ & 0 & 0 & 0 & $94.2 \pm 0,15$ \\
\hline
\end{tabular}

(a) randomized trials.

(b) conversion (\%) $=($ SODD initial acid value - acid value of reaction mixture at time t) $x 100 /$ SODD initial acid value. Values are expresses as $\bar{X} \pm \operatorname{SD}(n=3)$

$\mathrm{X}_{1}$ : reaction time $(\mathrm{h}) ; \mathrm{X}_{2}: \mathrm{H}_{2} \mathrm{SO}_{4}$ concentration (\% reactants weight); $\mathrm{X}_{3}$ : molar ratio of reactants (ethanol:free fatty acids in SODD).

a function of time. When a constant $\mathrm{AV}$ was reached, $5 \mathrm{~mL}$ of the reaction mixture was washed with water until complete mineral acid elimination. Excess moisture was eliminated in a vacuum oven (100 mbar pressure and $60^{\circ} \mathrm{C}$ temperature, for $\left.1.5 \mathrm{~h}\right)$.
Tocopherol determinations were also made, in all trials, in order to verify losses of these compounds during the esterification reaction.

Conversion yields: The percent of conversion of FFA to ethyl esters was determined by measuring the initial and final acid value of the reaction mixture.

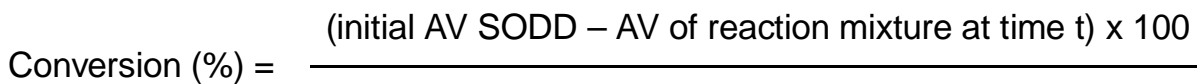


Table II

Variation levels (coded) of three independent variables for the direct acid esterification of soybean oil deodorizer distillate (SODD)

\begin{tabular}{l|ccccc}
\hline Independent & \multicolumn{5}{c}{ Coded level of variables } \\
\cline { 2 - 6 } Variables & $\mathbf{- 1 . 6 8 ^ { * }}$ & $\mathbf{- 1}$ & $\mathbf{0}$ & $\mathbf{+ 1}$ & $\mathbf{+ 1 . 6 8 ^ { * }}$ \\
\hline Time $\left(\mathrm{X}_{1}\right)$ & 0.2 & 0.7 & 1.5 & 2.3 & 2.8 \\
$\mathrm{H}_{2} \mathrm{SO}_{4}\left(\mathrm{X}_{2}\right)$ & 0.4 & 0.6 & 1.0 & 1.4 & 1.6 \\
Ethanol:FFA $\left(\mathrm{X}_{3}\right)$ & 2 & 4 & 7 & 10 & 12 \\
\hline
\end{tabular}

$\left(^{*}\right) \pm \alpha= \pm\left(2^{n}\right)^{1 / 4}= \pm 1.68(8)$

$\mathrm{X}_{1}$ : reaction time $(\mathrm{h}), \mathrm{X}_{2}: \mathrm{H}_{2} \mathrm{SO}_{4}$ concentration (\% substrate weight); $\mathrm{X}_{3}$ : reactantes molar ratio (ethanol:free fatty acids in SODD).

\section{RESULTS AND DISCUSSION}

Chemical characteristics and composition of the SODD sample are shown in Table III. The unsaponifiable matter analysis showed $8.55 \%$ of total tocopherols and $17.02 \%$ sterols. Only stigmasterol, campesterol and $\beta$-sitosterol, which were found in larger amounts, were considered. The results show that the SODD used has a trade standard quality for tocopherol concentration purposes (tocopherols content $>6 \%$, w/w) (Woerfel, 1981) and its composition was similar to those reported in literature (Winters, 1989).

As the moisture content of the reaction mixture was relatively low $(<1 \%)$, the FFA esterification with ethanol was the predominant reaction. Lipid classes analysis confirms this supposition, practically, no changes in mono-, di- and triacylglycerol concentrations were observed, therefore representing an insignificant contribuition of free fatty acids for ethyl ester formation. Under the conditions tested in this work, tocopherol losses were always below $5.5 \%$.

Conversions obtained during the reaction under different conditions are shown in Table I. The effects of the three independent variables: reaction time, $\mathrm{H}_{2} \mathrm{SO}_{4}$ concentration and ethanol: $\mathrm{FFA}$ molar ratio on the yield (response $Y$ ) are given in Table IV. It was verified that, except for the interaction effect reaction time by $\mathrm{H}_{2} \mathrm{SO}_{4}$ concentration, all variables, such as linear term, quadratic term and interactions, are statistically significant in the range studied and had a significant effect (positive or negative) on the percentage conversion of FFA to ethyl esters. In spite of being significant, the variable that caused the smallest effect on the response was the reaction time, in the range tested (0.2-2.8 $\mathrm{h}$ ), and the higher effect is caused by molar relation ethanol: FFA, in the range from 2 to $12 \%$.
Table III

Composition $\left(\mathrm{g} \mathrm{kg}^{-1}\right)$ of soybean oil deodorizer distillate (SODD)

\begin{tabular}{lc}
\hline \multicolumn{1}{c}{ Component } & SOD D \\
\hline Moisture & $2.4 \pm 0.02$ \\
Free fatty acid (as oleic) & $475.5 \pm 0.03$ \\
Monoacylglicerydes & $141.8 \pm 0.09$ \\
Diacylglicerydes & $64.3 \pm 0.15$ \\
Triacylglicerydes & $56.1 \pm 0.10$ \\
Unsaponifiable matter & $262.3 \pm 0.30$ \\
Total tocopherols & $85.5 \pm 0.19$ \\
$\alpha$-tocopherol & $16.1 \pm 0.05$ \\
$\beta$-tocopherol & $2.2 \pm 0.07$ \\
$\gamma$-tocopherol & $47.5 \pm 0.03$ \\
$\delta$-tocopherol & $19.7 \pm 0.04$ \\
Sterols & $170.2 \pm 0.15$ \\
Campesterol & $46.1 \pm 0.05$ \\
Stigmasterol & $38.5 \pm 0.08$ \\
$\beta$-sitosterol & $85.6 \pm 0.02$ \\
\hline
\end{tabular}

Values are expressed as $\overline{\mathrm{X}} \pm \mathrm{SD}(n=3)$

Results of the regression coefficients (Table IV), obtained by the statistical procedures, were used to 
Table IV

Effect estimate analysis of the three variables as a linear term (L), quadratic term (Q) and interactions (cross product) on the response $Y$ (\% conversion of free fatty acids to ethyl esters) of the central composite rotational design $\left(R^{2}=94.6 \%\right)$ for a second order model, at a significance level of $95 \%$

\begin{tabular}{c|c|c} 
Variable & Effect (\%) & $\begin{array}{c}\text { Regression } \\
\text { Coefficients }\end{array}$ \\
\hline Mean & 93.8 & 93.8 \\
(1) $\mathrm{Time} \mathrm{(L)}$ & 3.66 & 1.83 \\
(2) $\mathrm{H}_{2} \mathrm{SO}_{4}(\mathrm{~L})$ & 7.81 & 3.90 \\
(3) Ethanol:FFA (L) & 23.4 & 11.7 \\
$\mathrm{Time}(\mathrm{Q})$ & -6.11 & -3.06 \\
$\mathrm{H}_{2} \mathrm{SO}_{4}(\mathrm{Q})$ & -8.55 & -4.28 \\
Ethanol:FFA (Q) & -18.4 & -9.24 \\
1L by 3L & 3.10 & 1.55 \\
2L by 3L & 2.90 & 1.45 \\
\hline
\end{tabular}

fit a second order polynomial equation (coded model), given by:

$$
\begin{gathered}
Y=93.80+1.83 X_{1}+3.90 X_{2}+11.7 X_{3}-3.06 X_{1}{ }^{2}- \\
4.28 X_{2}^{2}-9.24 X_{3}^{2}+1.55 X_{1} X_{3}+ \\
1.45 X_{2} X_{3}+0.82
\end{gathered}
$$

The validation of the model was determined through analysis of variance (ANOVA) for the response $Y$ (Table $V$ ). An excellent reproducibility of the results is observed, since the pure error is very low (1.647), representing approximately $0.05 \%$ of the total variation source. The explained percentage variation around the average $\left(R^{2}=94.6 \%\right)$ was high, giving a correlation coefficient $(R)$ of 0.97 , between the observed responses and the values predicted by the model, thus indicating a good adjustment of the model obtained, at a significance level of $95 \%$. The residues are explained almost exclusively by the lack

Table V

Analysis of variance (ANOVA) for the response $Y$ (\% conversion of free fatty acids to ethyl esters) of the central composite rotational design $\left(R^{2}=94,6 \%\right)$ for a second order model, at a significance level of $95 \%$ of fit of the model, that represents approximately $5.3 \%$ of the total variation. Using the " $F$ " test, it was verified that the regression equation was statistically significant and predictive, since the calculated " $F$ " ratio (13.8) was 3.8 times greater than the value of the tabulated " $F$ " $\left(\mathrm{F}_{0.95 ; 9 ; 7}=3.68\right)$ (Barros Neto et al., 1996).

The optimization of the reaction conditions was obtained through the analysis of the adjusted surfaces of the model. The effects of the three independent variables on the extent of conversion of FFA to ethyl esters can be visualized on the contour plots (Figures 1-3). They were established by setting one of the variables in the central point and varying the other two, verifying the statistical results given in Table IV.

It was not found technical literature other previous studies about esters yields from direct acid esterification process.

\section{A) Ratio of reactants}

A molar excess of ethanol in relation to SODD FFA was found to be necessary to obtain optima conversions, up to $94 \%$. In preliminary studies, it was verified that increasing ethanol: FFA molar ratio from 4 to $10: 1$, resulted in an increase of $19.6 \%$ in the conversion of FFA to ethyl esters. The same effect was previously reported (Formo, 1954), when the esterification of fatty acids with monohydric alcohol was studied, where it was necessary an alcohol molar excess of $15-35$ based on fatty acids, to obtain esters yields up to $95 \%$. The significant linear effect that relation ethanol: FFA has on the conversion of FFA to ethyl esters (23.4) is shown in Table IV. Its interaction effect with the time is presented in Figure 1, where two ranges of ethanol: FFA molar ratio and one of time presented a decrease in the conversions: at low $(2.0-6.4: 1)$ and high $(11.2-12: 1)$ relations of reactants and at low reaction time $(0.2-0.6 \mathrm{~h})$. Thus, it can be concluded

\begin{tabular}{|l|c|c|c|c|}
\hline $\begin{array}{c}\text { Variation } \\
\text { Source }\end{array}$ & $\begin{array}{c}\text { Sum of } \\
\text { Squares }\end{array}$ & $\begin{array}{c}\text { Degrees of } \\
\text { Freedom }\end{array}$ & $\begin{array}{c}\text { Mean } \\
\text { Square }\end{array}$ & "F" Ratio \\
\hline Regression & 3,162 & 9 & 351.3 & 13.8 \\
Residual & 178.5 & 7 & 25.50 & 0.72 \\
Lack of Fit & 176.9 & 5 & 35.38 & \\
Pure Error & 1.647 & 2 & 0.824 & \\
TOTAL & 3,340 & 16 & 208.8 & \\
\hline
\end{tabular}




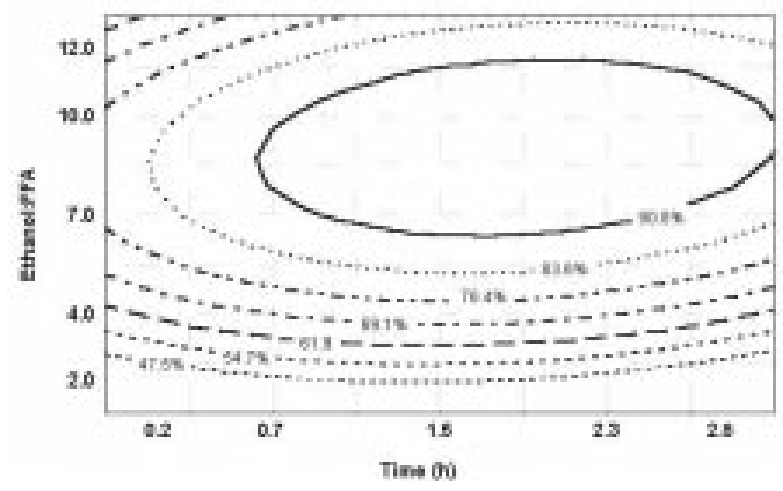

Figure 1

Two-dimensional contour plots showing the effect of ethanol: free fatty acids molar ratio and reaction time on the conversion of fatty acids to ethyl esters at $\mathrm{H}_{2} \mathrm{SO}_{4}$ of $1 \%$

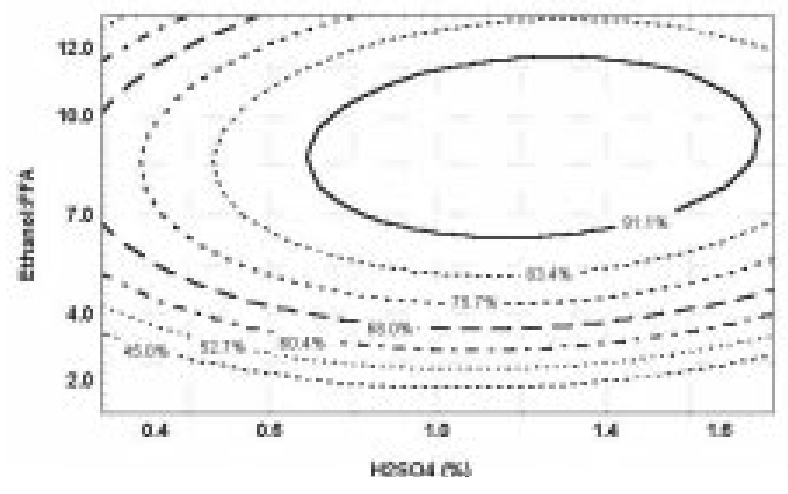

Figure 2

Two-dimensional contour plots showing the effect of ethanol: free fatty acids molar ratio and $\mathrm{H}_{2} \mathrm{SO}_{4}$ concentration on the conversion of free fatty acids to ethyl esters at reaction time of $1.5 \mathrm{~h}$.

that optimal conversions, above $90.8 \%$ were obtained for $\mathrm{H}_{2} \mathrm{SO}_{4}$ concentration set at $1 \%$, reaction time from 0.6 to $2.8 \mathrm{~h}$ and ethanol: FFA molar ratio from 6.4 to $11.2: 1$.

It can be said that the combined effect of ethanol: FFA molar ratio and $\mathrm{H}_{2} \mathrm{SO}_{4}$ concentration is vital to establish the kinetics and the reaction equilibrium of FFA conversion to ethyl esters (Fig 2). For reaction time set at 1.5 hours, a decrease of the conversion rate at $\mathrm{H}_{2} \mathrm{SO}_{4}$ concentration of $0.4-0.7 \%$, at ethanol: FFA molar ratio ranges of $2.0-6.4$ and of 11.2 12.0:1 was observed. Therefore, the best conversion (above $91.1 \%$ ) were obtained at ethanol: FFA ranges of $6.4-11.2: 1$, reaction time set at $1.5 \mathrm{~h}$ and $\mathrm{H}_{2} \mathrm{SO}_{4}$ concentration of $0.7-1.6 \%$.

It can be observed in Table IV, almost the same interaction effect of ethanol: FFA with reaction time (1 by 3 ) (3.10), in relation to catalyst concentration ( 2 by 3) (2.90), which can be checked through the contours plots (Figures 1 and 2), where practically the same range of the conversion variation was observed, from 47.5 to $90.8 \%$ for the interaction of

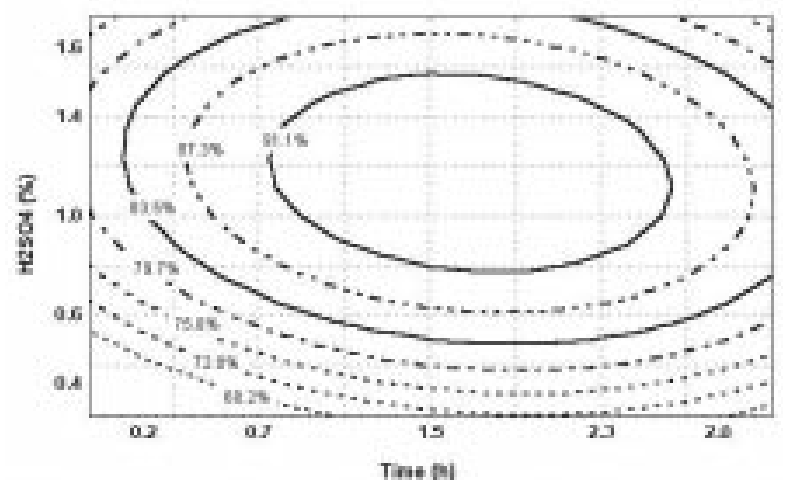

Figure 3

Two-dimensional contour plots showing the effect of $\mathrm{H}_{2} \mathrm{SO}_{4}$ concentration and reaction time on the conversion of free fatty acids to ethyl esters at ethanol: FFA of 7:1.

ethanol: FFA and time and from 45.0 to $91.1 \%$ for the interaction of ethanol: FFA and $\mathrm{H}_{2} \mathrm{SO}_{4}$ concentration (conversion results are presented into each Figure).

\section{B) Catalyst concentration}

The reaction velocity of carboxylic acids is proportional to $\mathrm{H}^{+}$ion concentration added at low concentration, normally $1-3 \%$ (reactants weight), to obtain esters yields up to 95\% (Formo, 1954; Morrison \& Boyd, 1992). Other authors state that in the direct chemistry reactions of fatty acids SODD with monohydric alcohols, it must be used mineral acid concentrations from 5 to 14 parts by weight of SODD, or pH varying from 0.3 to 1.5 (Brokaw and Smith, 1964).

In preliminary studies, it was verified that increasing the sulfuric acid concentration from 0.6 to $1.4 \%$, the extent of conversion increased by $5.85 \%$. The significant linear effect that $\mathrm{H}_{2} \mathrm{SO}_{4}$ has on the conversion of FFA to ethyl esters $(7,81)$ can be observed in Table IV. Its interaction effect with the reaction time can be evidenced in Figure 3, where two ranges of $\mathrm{H}_{2} \mathrm{SO}_{4}$ concentration presented a decrease in the conversions: at low $(0.4-0.8 \%)$ and at high (1.5 $-1.6 \%)$ catalyst concentrations and in two ranges of time, at low $(0.2-0.8 \mathrm{~h})$ and high $(2.6-2.8 \mathrm{~h})$ reaction time. Thus, it can be concluded that optimal conversions, above $91.1 \%$, were obtained for $\mathrm{H}_{2} \mathrm{SO}_{4}$ concentrations from 0.8 to $1.5 \%$, ethanol: FFA molar ratio set at 7:1, and reaction time from 0.9 to $2.6 \mathrm{~h}$.

In Table IV, it can be observed the interactive effect of catalyst with the ethanol: FFA molar ratio (2 by 3) (2.9). As it is not observed an interactive significant effect $(p>0.05)$ with the reaction time $(1$ by 2 ) on the conversion of FFA to ethyl esters, this interactive effect was not presented in this Table. The interaction effects of $\mathrm{H}_{2} \mathrm{SO}_{4}$ concentration with ethanol: FFA molar ratio and reaction time can be observed by the contours plots (Figure 2 and 3 ), where its higher interactive effect with reactants were 
evidenced with extent of conversion varying greatly (from 45.0 to $91.1 \%$ ).

\section{C) Reaction time}

In previous research, it was verified that to obtain a complete FFA esterification with monohydric alcohols, using mineral acid as catalyst, the reaction mixture must be refluxed, under high temperature, for about 1-2 hours (Brokaw and Smith, 1964). Besides, in preliminaries studies, it was verified that the increasing of reaction time from 0.7 to $2.3 \mathrm{~h}$ resulted in an increase of the extent of conversion of only $1.25 \%$. In Table IV, we can observe its interaction significant effect $(p<0.05)$ with the reactants (3.10) as well as the fact that the time is the variable that has the smallest effect on the conversion rate of FFA to ethyl esters when compared with $\mathrm{H}_{2} \mathrm{SO}_{4}$ concentration and ethanol: FFA molar ratio. Figures 1 and 3 are showing the interactive effects of reaction time with reactants and catalyst, respectively.

\subsection{Definition of Optima Process Conditions}

Through the intersection of the three contour plots, it can be concluded that the best region for the esterification reaction studied, in coded values can be obtained by the model is from -0.2 to 1.4 , for all the independent variables, which means that percent of conversion above $94 \%$ can be obtained with reaction times of $1.3-2.6 \mathrm{~h}, \mathrm{H}_{2} \mathrm{SO}_{4}$ concentrations of $0.9-$ $1.5 \%$ and ethanol: FFA molar ratio of $6.4-11.2: 1$.

\subsection{Validation of the Experimental Statistical Model}

The validation of the experimental statistical model obtained was determined using the lower values conditions amongst the optima conditions: time $=1.3 \mathrm{~h}, \mathrm{H}_{2} \mathrm{SO}_{4}$ concentration $=0.9 \%$ and ethanol: FFA molar ratio $=6 \cdot 4: 1$. A conversion of $90.6 \%$ was predicted using the model with the coded values. The experimental result obtained for the percent of conversion of FFA to ethyl esters, using the real values for the independent variables, was $92.7 \%$., thus verifying the observation that the model found is predictive.

\section{CONCLUSIONS}

Direct acid esterification was shown to be a technically viable process, which the best ranges for SODD FFA conversion to ethyl esters being: reaction time from 1.3 to $2.6 \mathrm{~h}, \mathrm{H}_{2} \mathrm{SO}_{4}$ concentration from 0.9 to $1.5 \%$ and ethanol:FFA molar ratio from 6.4 to $11.2: 1$. The yields obtained under these conditions were above
94\%. No significant tocopherol losses were observed during the SODD esterification process.

\section{ACKNOWLEDGMENTS}

This research was supported by "Fundação de Apoio à Pesquisa do Estado de São Paulo" (FAPESP), project number 98/15495-3 and Nara L. Facioli PhD fellowship from "Fundação de Coordenação de Aperfeiçoamento de Pessoal de Nível Superior" (CAPES).

\section{REFERENCES}

A.O.C.S. Official Methods and Recommended Practices of the American Oil Chemists' Society. (1997). V.1 and 2 , $4^{\text {th }}$. Firestone, D. Ed., AOCS Press, Champaign, IL.

Barros Neto, B., Scarminio, I.S. and Bruns, R.E. (1996). Planejamento e Otimização de Experimentos. p. 61-186. Editora Unicamp, Campinas, São Paulo.

Box, G.E.P., Hunter, W.G. and Hunter, J.S. (1978). Statistics goes Experiments. An Introduction to Design, Data Analysis and Model Building. pp. 653. Wiley \& Sounds Ed., New York.

Brokaw, W. and Smith, F.E. Process for Separating Tocopherols and Sterols from Deodorizer Sludge and the like. Patent U.S. № 3.153.055 (13.10.64).

Dobarganes, M.C. and Márquez-Ruiz, G. (1993). Size Exclusion Chromatography in the Analysis of Lipids in Advances in Lipids Methodology. p. 113-137. Christie, W.W. Ed. The Oil Press Ltd, Scotland.

Formo, M.W. (1954). Ester Reactions of Fatty Materials. J. Am. Oil Chem. Soc. 31, 548-559.

Holen, B. (1985). Rapid Separation of Free Sterols by Reversed-Phase High Performance Liquid Chromatography. J. Am. Oil Chem. Soc. 62, 1344-1346.

Khuri, A.I. and Cornell, J.A. (1987). Response Surfaces in Design and Analysi, pp 410. Owen, D.B. Ed. Ed.Marcel Dekker, New York.

Kim, S.K. and Rhee, J.S. (1982). Isolation and Purification of Tocopherols and Sterols from Soya Oil Deodorization. Korean J. Food Sci. Technol. 14, 174-182.

Morrison, R.T. and Boyd, R. (1992). Carboxylic Acids in Organic Chemistry, cap.19, p.713-752, $6^{\mathrm{a}}$. Ed. Prentice Hall International Inc., London.

Pryde, E.H. (1980). Composition of Soybean Oil in Handbook of Soy Oil Processing and Utilization, p. 13-31. Erickson, D.R., Pryde, E.H., Brekke, O.L., Mounts, T.L. and Falb, R.A. Ed. Ed. WING-AOCS, Champaign.

Ramamurthi, S., Bhirud, P.R. and McCurdy, A.R. (1991) Enzymatic Methylation of Canola Oil Deodorizer Distillate. J. Am. Oil Chem. Soc. 68, 970-975.

Winters, R.L. (1989). Basic Principles and Modern Practices in Proceedings World Conference on Edible Fats and Oils Processing, p. 186-238. Erickson, D.R.Ed. AOCS Press, Champaign, IL.

Woerfel, J.B. (1981). Processing and Utilization of By-Products from Soy Oil Processing. J. Am. Oil Chem. Soc. 58, 188-191. 